\title{
Türkiye'de Maden İşletmelerinde Yatırım Teşvik Uygulaması Ve Örneklerle Muhasebe Kayıtları ${ }^{1}$
}

\section{Muhammed Mustafa KISAKÜREK}

Prof. Dr., Kahramanmaraş Sütçü İmam Üniversitesi, İktisadi ve İdari Bilimler Fakültesi, İşletme Bölümü mmk_46@hotmail.com

Orcid ID: https://orcid.org/0000-0003-2351-4314

\section{Seval ELDEN ÜRGÜP}

Dr. Öğr. Üyesi, Sivas Cumhuriyet Üniversitesi, İktisadi ve İdari Bilimler Fakültesi, İşletme Bölümü sevalelden@hotmail.com

Orcid ID: https://orcid.org/ 0000-0002-7464-3485

\section{Mesut TATLI}

Serbest Muhasebeci/Mali Müşavir, mesuttatli46@gmail.com

Orcid ID: https://orcid.org/0000-0002-8345-7713

\section{Öz}

Türkiye'de özellikle son yıllarda madencilik sektörünün gelişmesine paralel olarak mevzuatta bazı değişiklikler yapılmıştır. Yatırımları desteklemek için yapılan teşvikler sürekli olarak güncellenmesine rağmen gerek sektöre yönelik vergisel düzenlemeler gerekse de sektöre özel teşvik uygulamalarına duyulan ihtiyaç her geçen gün giderek artmaktadır. Madencilik sektöründe faaliyet gösteren işletmelerin ekonomi içindeki yeri, kendilerine has yapısı ve çoğunun çok uluslu işletme özelliği göstermesi finansal tablolarında sundukları bilgilerin anlaşılır ve karşılaştırılabilir olması açısından önem arz etmektedir. Bu yüzden, devlet teşviki, işletme tarafından teşvikin elde edilmesi için gerekli koşulları yerine getireceğine ve teşvikin elde edileceğine dair makul bir güvence olmadan finansal tablolarına yansitılamaz.

Çalışmanın amacı, maden sektöründe faaliyette bulunan krom maden işletmesinin yatırım teşvik belgesi kapsamında yatırım harcaması yaparak

\footnotetext{
${ }^{1}$ Makale Geliş/Kabul Tarihi: 18.02.2020 / 03.10.2020

Künye Bilgisi: Klsakürek, M., Elden Ürgüp, S. ve Tatl, M. (2020). Türkiye'de Maden Işletmelerinde Yatırım Teşvik Uygulaması Ve Örneklerle Muhasebe Kayıtları. Kahramanmaraş Sütçü İmam Üniversitesi Sosyal Bilimler Dergisi, 17 (2), 1135-1163. DOI: $10.33437 /$ ksusbd.690792
} 
yatırım indirimi istisnalarından yararlanırken yapılması gereken muhasebe kayıtları örnekler yardımıyla açıklamaktır. Bu kapsamda, işletmenin yatırım teşvik belgesi alınmasından başlanılarak yapılması gereken muhasebe kayıtları, işlemlerle alakalı bilgiler ve hesaplamalar Ekonomi Bakanlığı'nın belirlediği kriterlere ve ilgili mevzuata uygun bir şekilde ilgili örnekler yardımıyla ele alınmıştır.

Sonuç olarak, örnek olarak seçilen işletmenin yatırım indiriminden yararlandığı tespit edilmiştir. Ayrıca, işletmenin mevzuatta yer alan uygulama esaslarını benimsediği için işletmeden bilgi alacak olan karar alıcıları da yanıltmadığı sonucuna ulaşılmıştır.

Anahtar Kelimeler: Maden İşletmesi, Devlet Teşvikleri, Maden İşletmelerinde Devlet Teşvikleri ve Muhasebeleştirilmesi.

\title{
Investment And Accounting Promote Their Application In The Sample Records Turkey Mine
}

\begin{abstract}
In Turkey, some changes have been made in the legislation in parallel with the development of the mining sector, especially in recent years. Although incentives to support investments are constantly updated, the need for both tax regulations for the sector and sector-specific incentives are increasing day by day. The place of the companies operating in the mining sector in the economy, their unique structure and the fact that most of them have multinational business characteristics are important in terms of being understandable and comparable in the financial statements. Therefore, government incentives cannot be reflected in their financial statements without reasonable assurance that the business will meet the conditions required to obtain the incentive and that the incentive will be obtained.

The purpose of the study is to explain with the help of examples the accounting records that need to be made while benefiting from the investment incentive exemptions by making investment expenditures within the scope of the investment incentive certificate of the chrome mining company operating in the mining sector. In this context, the accounting records, transactions related information and calculations to be made starting from obtaining the investment incentive certificate of the enterprise have been handled with the help of relevant
\end{abstract}




\section{Kısakürek - S. Elden Ürgüp - M. Tatlı Türkive'de Maden İsletme...}

examples in accordance with the criteria set by the Ministry of Economy and the relevant legislation.

As a result, it was determined that the company selected as an example benefited from investment incentives. In addition, it has been concluded that the company does not mislead decision-makers who will receive information from the company, since it has adopted the principles of practice in the legislation.

Keywords: Mining Plant, Government Incentives, Government Incentives and Accounting in Mining Enterprises.

\section{GíRIș}

Ulusal ekonomiye katma değer katan sektörlerden biri de "Madencilik Sektörü"'dür. Madencilik sektörü, bir taraftan başta sanayi olmak üzere, ekonominin diğer sektörlerinin ihtiyaç duyduğu temel girdileri sağlarken diğer taraftan, özellikle kırsal bölgelerde yeni istihdam alanları oluşturur. Bu bölgelerde başta ulaşım olmak üzere, önemli altyap1 yatırımlarının gerçekleşmesini sağlar. Çağdaş teknoloji, pazarlama ve finansman yöntemleri, madencilik sektörünün gelişmesine paralel olarak ülkenin kırsal bölgelerinde benimsenip yaygınlaşır. Bir başka yönden, madencilik ürünleri ihracatı ülkeye döviz kazandıran önemli bir kaynaktır. Bugünün gelişmiş sanayi ülkelerinin hemen hepsinde madencilik sektörü, ekonomik kalkınmayı başlatan bir "öncü sektör" görevi yüklenmiştir.

Madencilik sektörü ekonominin temel çarklarından biri olmasına karşın, sektöre yönelik sabit sermaye yatırımlarının toplam yatırımlar içerisindeki payı sadece $\% 2$ civarındadır. Bu düşük sabit sermaye yatırımı, bugüne kadar ülkenin maden kaynaklarının efektif bir biçimde değerlendirilerek katma değeri yüksek ürünlere geçiş sağlayabilecek sermaye birikiminin sağlanamadığının açık bir göstergesidir.

Yatırımlara sağlanan devlet yardımları 19.06.2012 tarihli ve 3305 sayılı "Yatırımlarda Devlet Yardımları Hakkında Karar" ile bu Karar'a ilișkin düzenlenen 2012/1 sayılı Tebliğ çerçevesinde yeni teşvik sistemi ile uygulanmaktadır. Madencilik yatırımları gerek şu anda yürürlükte bulunan Karar gerekse daha önceki Kararlar döneminde azami ölçüde desteklenen sektörler arasında yerini almaktadır.

Devlet teşvik politikalarının amaçları, üretimi ve istihdamı artırmak, bölgesel gelişmişlik farklılıklarını gidermek, uluslararası rekabet gücünü artıracak teknoloji ve araştırma-geliştirme içeriği yüksek büyük ölçekli yatırımları 
özendirmek, doğrudan yabancı yatırımları artırmak, yatırım eğilimin devamlılığını ve bununla beraber sürdürülebilir kalkınmayı sağlamaktır.

Bu çalışmada öncelikle madencilik sektörü ve maden işletmeciliği açıklanmış ve maden sektörüne sağlanan devlet teşvikleri üzerinde durulmuştur.

Daha sonra devlet teşviklerinin muhasebeleştirilmesi ele alınarak, teşvik unsurlarının muhasebe kayıtları örnekler yardımıyla açıklanmıştır.

\section{MADENCİLIK SEKTÖRÜ VE MADEN ISŞLTMECILIIĞİ HAKKINDA GENEL BILGILER}

Madencilik sektörü küresel olarak özel bir öneme sahiptir. Bu nedenle ki, ülke ekonomilerinin ihtiyaç duyduğu temel hammaddeleri sağlamakta, birçok sanayi kolunun ilk tedarikçi olarak rol almakta ve diğer sektörler için önemli bir pazar niteliği taşımaktadır. Hatta tarım sektöründen sonra insan hayatında önemli bir yer tutan ikinci sektördür. Gelişmiş ülkelerin bugün sahip oldukları teknoloji ve refah düzeyinde en aktif rol oynayan faktörlerden biri de hiç şüphesiz madencilik sektörü olmuştur. TBMM Madencilik Araştırma Komisyon Raporu'na göre Dünyada her yıl 1,5 trilyon ABD doları değerinde, 10 milyar ton civarında maden üretimi yapılmaktadır. Bu üretimin \%75'ini enerji hammaddeleri \%10'unu metalik madenler ve \%15'ini ise endüstriyel hammaddeler oluşturmaktadır. Bu büyüklüklere bakıldığında madencilik sektörünün, bir yandan ekonomiye yaptı̆̆ 1 katkı bir yandan da özellikle imalat sanayiine sağladığı girdiler nedeniyle önemi daha da artmakta, ekonominin itici gücü olmaktadır. Bu veriler doğrultusunda madencilik sektörünün dünya ekonomisi adına ne kadar önemli olduğu ortaya çıkmaktadır(Sönmez,2016:316). Diğer taraftan dünyada enerji ihtiyacının artması ülkeleri yer altı kaynaklarının etkin şekilde kullanılmasını zorunlu hale getirmiştir. Bu yüzden madencilik sektörü her geçen gün giderek büyüyen ve yatırım potansiyeli sürekli olarak artan bir sektör olmuştur (Yardımcıŏglu vd., 2014:73).

Literatürde maden işletmeciliği ile ilgili yapılan en kapsamlı tanım; maden işletmeleri, yer kabuğunda bulunan maden yataklarının; aranması, araştırılması, değerlendirilmesi, geliştirilmesi, çıkarılması, zenginleştirilmesi ve satışa hazır hale getirilmesi işlemlerini kâr elde etmek amacıyla sürdüren işletmelerdir. Maden işletmeleri farklı üretim yöntemleri kullanarak maden cevherini doğal damarından koparır, satışa hazır maden haline getirir veya işletme kendisi bu madeni tekrar işleyerek ürün olarak satar. Maden işletmeleri, tükenen ve yeniden üretilmesi mümkün olmayan doğal kaynakların üretimi ile uğraşırlar. Rezervin sınırlı olması nedeniyle, çoğunlukla işletmelerin ömrü de rezerv ile birlikte sonlanabilmektedir (Demir ve Çiftçi, 2017: 596). 


\section{Kısakürek - S. Elden Ürgüp - M. Tatlı Türkive'de Maden İsletme...}

Maden işletmeleri diğer üretim işletmeleriyle kıyaslandığında bazı farklı özelliklerinin olduğu görülmektedir. Söz konusu özellikler aşağıdaki gibi sıralanmıştır (Özkan ve Aksoylu, 2012:79-81):

$\checkmark$ Tükenen ve yeniden üretilmesi mümkün olmayan doğal kaynaktan üretim yapmaları,

$\checkmark$ Madenin çıkarılması (üretim) aşamasına gelinceye kadar; araştırma, değerlendirme ve üretime hazırlık gibi ön çalışmalar yapmaları,

Büyük çapta doğal olayların etkisi altında olmaları ve bundan dolayı diğer üretim işletmelerindeki risklere ilave olarak önemli ölçüde başarısızlık ve zarar riski ile karşı karşıya olmaları,

$\checkmark \quad$ Her yeni maden bölgesi için risk ve belirsizlik söz konusu olması,

$\checkmark \quad$ Genellikle maden rezervlerinin dağınık halde bulunması ekonomik işletme yöntemlerinin uygulanmasını engellemesi,

$\checkmark$ Madencilik faaliyetlerinin gerçekleşmesi uzun zaman alması ve dolayısıyla hasılatın elde edilmesinde de gecikmelerin meydana gelmesi,

$\checkmark \quad$ Maden çıkarılan sahanın doğal halinin bozulmasını ortadan kaldırmak ve eski haline yeniden getirmek için ilave sonlandırma maliyetleri ile karşı karşıya kalınması,

$\checkmark$ Maden çıkaran işletmeler çevresel tahribatlara sebep olduğundan dolayı bazı çevreci sivil toplum kuruluşlarının tepkisi ile de karşılaşabilmeleri

$\checkmark \quad$ Çevreye karşı olan sosyal sorumlulukları şeklinde sıralanabilir.

Madencilik işletmelerinin yukarıda sıralanan özelliklerinin yanı sıra üretim öncesi, üretim aşaması ve üretim sonrası faaliyetlere ilişkin olarak ortaya çıkan maliyetler ve bunlara ilişkin muhasebe uygulamaları konusunda da önemli farklılıklar bulunmaktadır (Karapınar vd., 2010:47).

\section{MADENCİLIKK SEKTÖRÜNE SAĞLANAN DEVLET TEŞVİKLERİ}

Teşvik, bir takım ekonomik faaliyetlerin hızlı bir şekilde gelişmesini sağlamak için devlet tarafından çeşitli yöntemlerle verilen maddi ve maddi olmayan destek, yardım ve özendirmelerdir. Diğer bir tanıma göre teşvik, devlet tarafından çeşitli amaçlarla özel veya kamu teşebbüslerine karşıllklı ya da karşılıksız bir şekilde yapılan ayni veya nakdi yardımlar şeklinde tanımlanmaktadır (Yıldız vd., 2012:297). 
Teşviklerin amacı, kalkınma planları ve yıllık programlarda öngörülen hedefler ile uluslararası anlaşmalara uygun olarak, tasarrufları katma değeri yüksek yatırımlara yönlendirmek, üretimi ve istihdamı artırmak, yatırım eğiliminin sürekliliğini ve sürdürülebilir kalkınmayı sağlamak, uluslararası rekabet gücünü artıracak teknoloji ve araştırma geliştirme içeriği yüksek büyük ölçekli yatırımları özendirmek, doğrudan yabancı yatırımları artırmak, bölgesel gelişmişlik farklılıklarını gidermek, çevre korumaya yönelik yatırımlar ile araştırma ve geliştirme faaliyetlerini desteklemektir(Kara ve Topçu,2015:12). Ülkemizde yatırımları desteklemek için yatırımcılara çok çeşitli teşvikler sağlanmakta ve teşvik sistemi sürekli olarak güncellenmektedir. Teşviklerle ilgili güncel düzenleme 19 Haziran 2012 tarihinde alınan 3305 sayılı "Yatırımlarda Devlet Yardımları Hakkında Karar" ile yürürlüğe girmiş; Kararın uygulanmasına ilişkin usul ve esaslar da 2012/1 say1lı Tebliğ ile yeni teşvik sistemi belirlenmiştir (ekonomi.gov.tr, 2019).

Yeni teşvik sistemiyle birlikte Türkiye'nin en önemli sorunlarından biri olan cari açığın önlenmesi amaçlanmıştır. $\mathrm{Bu}$ amaç, ara malı üretiminin, ileri teknolojik yatırımların ve stratejik özellikli yatırımların desteklenmesi ile gerçekleşecektir. Teşvik sistemi uygulamaları dört gruptan oluşur. $\mathrm{Bu}$ uygulamalar ve destek unsurları Tablo 1'de yer almaktadır (Onay, 2016:34):

Tablo1.Destek Unsurları ve Teşvik Uygulamaları

\begin{tabular}{|l|c|c|c|c|}
\hline $\begin{array}{l}\text { Destek } \\
\text { Unsurları }\end{array}$ & $\begin{array}{c}\text { Genel } \\
\text { Teşvik } \\
\text { Uygulama } \\
\text { ları }\end{array}$ & $\begin{array}{c}\text { Bölgesel } \\
\text { Teşvik } \\
\text { Uygulamal } \\
\text { arı }\end{array}$ & $\begin{array}{c}\text { Bölgesel } \\
\text { Ölçekli } \\
\text { Yatırım } \\
\text { Teşviki }\end{array}$ & $\begin{array}{c}\text { Strateji } \\
\text { k } \\
\text { Yatırım } \\
\text { ların } \\
\text { Teşviki }\end{array}$ \\
\hline $\begin{array}{l}\text { KDV } \\
\text { İstisnas1 }\end{array}$ & $\square$ & $\square$ & $\square$ & $\square$ \\
\hline $\begin{array}{l}\text { Gümrük } \\
\text { Vergisi } \\
\text { Muafiyeti }\end{array}$ & $\square$ & $\square$ & $\square$ & $\square$ \\
\hline $\begin{array}{l}\text { Vergi } \\
\text { İndirimi }\end{array}$ & & & & \\
\hline $\begin{array}{l}\text { Sigorta } \\
\text { Primi } \\
\text { İşveren } \\
\text { Hissesi } \\
\text { Desteği }\end{array}$ & & $\square$ & $\square$ & $\square$ \\
\hline $\begin{array}{l}\text { Gelir } \\
\text { Vergisi }\end{array}$ & & $\square$ & $\square$ & $\square$ \\
\hline
\end{tabular}




\section{Kısakürek - S. Elden Ürgüp - M. Tatlı Türkive'de Maden İsletme...}

\begin{tabular}{|l|c|c|c|c|}
\hline Stopaji & & & & \\
Desteği & Sigorta & $\square$ & $\square$ & $\square$ \\
Primi & & & & \\
Desteği & & $\square$ & & $\square$ \\
\hline Faiz & & & \\
Desteği & & & & $\square$ \\
\hline Yatırım & Yeri & & & \\
Tahsisi & KDV & & & $\square$ \\
\hline İadesi & & & & \\
\hline
\end{tabular}

Kaynak: ekonomi.gov.tr, 2019.

Yeni teşvik sistemiyle beraber Türkiye'de ilk defa kapsamlı bir bölgesel teşvik sistemine geçilmiştir. $\mathrm{Bu}$ teşvik sistemi illerin özelliklerini ve potansiyellerini dikkate almaktadır. Böylece, bölge bazında kademelendirilmiş, teşvik araçlarıyla desteklenmiş bir sistem haline gelmiştir. Teşvik sistemi hem Avrupa Birliğinin bölgesel politikalarına uygun hem de günümüzün bölgesel gelişme eğilimlerine uygun bir şekilde tasarlanmaya çalışılmıştır. Yeni sistemde ekonomik gelişmişlik düzeyine göre altı farklı bölge belirlenmiştir. Bu bölgeler yapılan yatırım teşvik sisteminin destek unsurlarından farklı oranlarda faydalanacaklardır. Teşvik sisteminde belirlenen bölgeler Tablo 2'de gösterilmiştir (Onay, 2016:34).

Tablo 2. Bölgesel Gelişmişlik Düzeyleri 


\begin{tabular}{|c|c|c|c|c|c|}
\hline $\begin{array}{l}\text { 1.BÖL } \\
\text { GE }\end{array}$ & $\begin{array}{l}\text { 2. } \\
\text { BÖLGE }\end{array}$ & $\begin{array}{l}\text { 3. } \\
\text { BÖLGE }\end{array}$ & $\begin{array}{l}4 . \\
\text { BÖLGE }\end{array}$ & $\begin{array}{l}5 . \\
\text { BÖLGE }\end{array}$ & $\begin{array}{l}6 . \\
\text { BÖLGE }\end{array}$ \\
\hline $\begin{array}{l}\text { Ankara } \\
\text { Antalya } \\
\text { Bursa } \\
\text { Eskişeh } \\
\text { ir } \\
\text { İstanbul } \\
\text { İzmir } \\
\text { Kocaeli } \\
\text { Muğla }\end{array}$ & $\begin{array}{l}\text { Adana } \\
\text { Aydın } \\
\text { Bolu } \\
\text { Çanakka } \\
\text { le } \\
\text { Denizli } \\
\text { Edirne } \\
\text { Isparta } \\
\text { Kayseri } \\
\text { Kırklare } \\
\text { li Konya } \\
\text { Sakarya } \\
\text { Tekirda } \\
\breve{g} \\
\text { Yalova }\end{array}$ & $\begin{array}{l}\text { Balıkesi } \\
\text { r Bilecik } \\
\text { Burdur } \\
\text { Gaziant } \\
\text { ep } \\
\text { Karabük } \\
\text { Karama } \\
\text { n } \\
\text { Manisa } \\
\text { Mersin } \\
\text { Samsun } \\
\text { Trabzon } \\
\text { Uşak } \\
\text { Zonguld } \\
\text { ak }\end{array}$ & $\begin{array}{l}\text { Afyon } \\
\text { Amasya } \\
\text { Artvin } \\
\text { Bartın } \\
\text { Çorum } \\
\text { Düzce } \\
\text { Elazığ } \\
\text { Erzinca } \\
\text { n Hatay } \\
\text { Kastam } \\
\text { onu } \\
\text { Kırıkkal } \\
\text { e } \\
\text { Kırşehir } \\
\text { Kütahya } \\
\text { Malatya } \\
\text { Nevssehi } \\
\text { r Rize } \\
\text { Sivas }\end{array}$ & $\begin{array}{l}\text { Adıyam } \\
\text { an } \\
\text { Aksaray } \\
\text { Bayburt } \\
\text { Çankırı } \\
\text { Erzurum } \\
\text { Giresun } \\
\text { Gümüşh } \\
\text { ane } \\
\text { Kahram } \\
\text { anmaraş } \\
\text { Kilis } \\
\text { Niğde } \\
\text { Ordu } \\
\text { Osmani } \\
\text { ye } \\
\text { Sinop } \\
\text { Tokat } \\
\text { Tunceli } \\
\text { Yozgat }\end{array}$ & $\begin{array}{l}\text { Ağrı } \\
\text { Ardahan } \\
\text { Batman } \\
\text { Bingöl } \\
\text { Bitlis } \\
\text { Diyarba } \\
\text { kır } \\
\text { Hakkari } \\
\text { Iğdır } \\
\text { Kars } \\
\text { Mardin } \\
\text { Muş } \\
\text { Siirt } \\
\text { Şanlıurf } \\
\text { a Şırnak } \\
\text { Van }\end{array}$ \\
\hline $8 \dot{\mathrm{IL}}$ & 13 İL & 12 İL & 17 İL & 16 İL & 15 İL \\
\hline
\end{tabular}

Kaynak: ekonomi.gov.tr, 2019

İller ekonomik ölçek büyüklükleri ve gelişme potansiyelleri dikkate alınarak altı farklı gelişmişlik seviyesine ayrılmıştır. Devletin yatırımcıya yapacağ 1 yardımın büyüklüğü, vereceği destek oranı, sağlayacağı destek unsuru da bu gelişmişlik düzeylerine göre farklılık göstermektedir (Onocak ve Çukacı, 2018:119).

Madencilik yatırımları gerek şu anda yürürlükte bulunan karar gerekse daha önceki kararlar döneminde azami ölçüde desteklenen sektörler arasında yerini almıştır (Yolcu ve Sağlam, 2014:113).

\section{DEVLET TEŞVIKKLERINIIN MUHASEBELEŞTİIILMESI}

Türkiye'de devlet teşviklerinin muhasebeleştirilmesi ve raporlanması konusu Avrupa Birliği hibelerinin muhasebeleştirilmesinin gündeme gelmesi ile birlikte daha çok önem kazanmıştır. Maliye Bakanlığı tarafından Avrupa Birliği hibe tutarlarının muhasebeleştirilmesi ile ilgili 27.11.2007 tarih ve 26713 sayılı Resmi Gazete'de "Avrupa Birliği ve Uluslararası Kuruluşların Kaynaklarından Kamu İdarelerine Proje Karşılığı Aktarılan Hibe Tutarlarının Harcanması ve 


\section{Kısakürek - S. Elden Ürgüp - M. Tatlı Türkive'de Maden İsletme...}

Muhasebeleştirilmesine İlişkin Yönetmelik” yayınlanmıştır. Bu yönetmeliğin amacı, Avrupa Birliği, uluslar arası kuruluşlar veya uluslar arası konsorsiyumlardan kapsam dahilinde kamu idarelerine proje karşılı̆g 1 aktarılan hibe niteliğindeki tutarların uluslar arası anlaşma hükümleri saklı kalmak kaydıyla izlenmesi, harcanması ve muhasebeleştirilmesini belirlemektedir (Ulusan, 2008:416) (resmi gazete.gov.tr).

Devlet teşvikleri; destek, sübvansiyon veya prim olarak da adlandırılır. Devlet teşviki, işletme tarafindan teşvikin elde edilmesi için gerekli koşulları yerine getireceğine ve teşvikin elde edileceğine dair makul bir güvence olmadan finansal tablolara yansıtılmaz. Devlet teşvikinin fiilen elde edilmesi, teşvike ilişkin koşulların yerine getirildiği veya getirileceği anlamına gelmez. Devlet teşvikinin elde edilme şekli, teşvikin muhasebeleştirilme yöntemini etkilemez. Buna göre devlet teşvikleri nakden veya devlete olan bir yükümlülüğün azaltılması şeklinde elde edilmiş olsa dahi aynı şekilde muhasebeleştirilir. Devlet teşviklerinin muhasebeleştirilmesine ilişkin iki genel yaklaşım bulunmaktadır. Teşvikin kar veya zarar dışında muhasebeleştirildiği "sermaye yaklaşımı" ve teşvikin bir veya daha fazla dönemde kar ya da zararda muhasebeleştirildiği "gelir yaklaşımıdır"(Yolcu ve Sağlam, 2014:180).

Sermaye yaklaşımında, devlet teşvikleri bir maliyeti olmayan ve geri ödemesi beklenilmediğinden kazanılmış bir gelir olarak değerlendirilmezler, bu nedenle kar veya zararda muhasebeleştirmek yerine, finansal durum tablosu (bilanço) ile ilişsilendirilir. Gelir yaklaşımında, işletmenin önceden belirlenen koşullara uyması ve yükümlülüklerini yerine getirmesi sonucunda hak kazanması durumunda, ilgili teşviklerle karşılanan maliyetlerin gider olarak muhasebeleştirildiği dönemler boyunca sistematik bir biçimde kar ya da zararda muhasebeleştirilir. Teşvik ve sübvansiyonlar ancak elde edilecekleri kanaatini oluşturan ilgili bütün şartların tamamlanmasında sonra gelir kaydedilir. Maddi duran varlık edinilmesiyle ilgili olmayan teşvik ve sübvansiyonlar doğrudan gelir kaydedilerek muhasebeleştirilir (Tunçez ve Ateş, 2016:92-93).

Devlet teşviklerinin muhasebeleştirilmesi ve raporlanmasında dikkat çeken nokta, devlet teşviklerinin gelecekte belirli şartları sağlayıp sağlamaması konusudur. Bu açıdan bakıldığı zaman aşağıda sıralanan maddeler bu doğrultuda ele alınarak muhasebeleştirilmelidir (Karasioğlu ve Kınalı, 2017:143). Bunlar:

İşletme tarafından kullanılan devlet teşviklerinin gelecekte belirli şartları sağlaması istenmiyorsa, teşvikler alındıkları anda muhasebe sisteminde gelir olarak,

$\checkmark \quad$ İşletme tarafından kullanılan devlet teşviklerinin gelecekte belirli şartları sağlaması istenirse, istenilen şartlar sağlandığı anda muhasebe bilgi sisteminde gelir olarak ve 
$\checkmark$ "Hasılatın muhasebeleştirilmesi” şartları karşılanmadan önce kullanılan teşvikler, muhasebe sisteminde borç olarak muhasebeleştirilmelidir.

\section{LITERATÜR TARAMASI}

Maden işletmeleri hakkında literatür incelendiğinde, bu konuda çok çeşitli çalışmalar yapıldığı görülmektedir. Sönmez (2005) çalışmasında işletmelerin devlet teşvik ve yardımlarından yaralanması durumunda muhasebe kayıtlarının TMS ve SPK açısından ne şekilde muhasebeleştirileceğini incelemiştir. Her iki düzenlemenin de birbirine benzer olduğu ve böylece uygulama ile düzenlemelerin birbirini tamamladığ sonucuna ulaşılmıştır.

Karapınar vd. (2010) madencilik sektöründe faaliyette bulunan işletmelerin IFRS 6 kapsamında getirdiği düzenlemeler ile genel kabul görmüş muhasebe politikaları karşılaştırmalı olarak incelemişlerdir. Çalışmanın sonucunda, IFRS 6'nın belirli bir politika belirlemekten uzak olduğu ve esnek düzenlemelere yer verdiği tespit edilmiştir.

Acar ve diğerleri (2012) çalışmalarında, bir mermer işletmesinde faaliyet tabanlı maliyetleme yöntemini kullanarak mermerin metre karesini yeniden hesaplamaya çalışmışlardır. Çalışma sonunda işletmenin hesapladığ metrekare maliyeti gerçeği tam olarak yansıtmadığını tespit etmişlerdir.

Özkan ve Aksoylu (2012) maden işletmelerinin yapmış oldukları harcamaların üretim süreçlerinde nasıl muhasebeleştirilecekleri üzerinde durmuşlardır. Bu kapsamda üretim öncesine ilişkin araştırma ve değerlendirme varlıklarına yönelik TFRS 6 ele alınmıştır. Çalışmanın sonucunda TFRS 6'nın maden işletmelerindeki süreçler ve ihtiyaçlar çerçevesinde yeniden düzenlenmesi gereğini ortaya koymuşlardır.

Yıldız vd. (2012) çalışmalarında sanayi sektöründeki işletmelerin aldıkları teşviklerin/hibelerin TMS 20 Standardı çerçevesinde gelir yaklaşımı ve sermaye yaklaşımına göre muhasebeleştirilmesi ve farklılıkların ortaya konması amaçlamışlardır. Çalışmanın sonucunda kullanılan tüm teşviklerin gelir yaklaşımına göre kayıt edilmesinde muhasebe sistemi açısından bir sakınca olmadığı ortaya çıkmıştır. Ancak devlete ödenecek vergi noktasında bir takım farklılıklar meydana gelmiştir.

Buyruk (2013) maden işletmelerinin yapmış oldukları harcamaların üretim süreçlerinde nasıl muhasebeleştirilecekleri üzerinde durmuştur. Çalışmanın sonucunda, TFRS 6'nın maden işletmelerindeki süreçler ve ihtiyaçlar çerçevesinde yeniden düzenlenmesi gerektiği ortaya çıkmıştır. 


\section{Kısakürek - S. Elden Ürgüp - M. Tatlı Türkive'de Maden İsletme...}

Yardımcıoğlu vd. (2014) çalışmalarında maden işletmelerinin yapmış oldukları harcamaların üretim süreçlerinde nasıl muhasebeleştirilecekleri üzerinde durmuşlardır. Çalışmanın sonucunda, TFRS 6'nın maden işletmelerindeki süreçler ve ihtiyaçlar çerçevesinde yeniden düzenlenmesi gereğini ortaya koymuşlardır.

Gerekan ve Gerekan (2014) TFRS 6 kapsamında muhasebe esaslarını belirtmekle beraber petrol arama, geliştirme, değer düşüklüğü, amortisman giderlerini muhasebe kayıtları ile ilgili bir örnek çalışma yapmışlardır. Çalışmada, petrol arama öncesinde ortaya çıkan harcamaların dönem gideri olarak kayıtlara aktarılmasının, ayrıca ruhsat edinimindeki maliyetlerin maddi olmayan duran varlık olarak Haklar Hesabı'nda izlenmesinin mümkün olduğu ifade edilmiştir.

Okutmuş ve diğerleri (2015) sağlık sektöründeki; Çelik ve diğerleri (2015) işletmelerin aldıkları teşviklerin/hibelerin TMS 20 Standardı çerçevesinde muhasebeleştirilmesiyle ilgili çalışma yapmışlardır.

Tunçez ve Ateş (2016) turizm sektöründe işletmelerin aldıkları teşviklerin/hibelerin TMS 20 Standardı çerçevesinde muhasebeleştirilmesiyle ilgili çalışma yapmışlardır.

Onay (2016) işletmelerin aldıkları teşviklerin/hibelerin TMS 20 Standardı çerçevesinde nasıl muhasebeleştirileceği ve finansal tablolarda nasıl sunulacağ 1 incelenmiştir.

Coşkun (2016) çalışmasında teşvik kapsamında alınan maddi duran varlıkların Muhasebe Standartları kapsamında örnek muhasebe kayıtları üzerinde açıklamaya çalışmıştır. Çalışmanın sonucunda, teşvik destek unsurlarının sermaye yaklaşımına göre kaydedilmesi işletmeler açısından daha gerçekçi olacağı belirtilmiştir.

Demir ve Çiftçi (2017) çalışmalarında maden üreten işletmelerde, işletmenin yapısına ve üretim süreçlerine uygun bir maliyet muhasebesi sisteminin özelliklerini araştırmayı ve böylelikle bu sektörde faaliyette bulunan işletmelere katk1 sağlayabilecek öneriler sunmayı amaçlamışlardır. Araştırma sonucunda çalışmalarında örnek aldıkları maden işletmesinin birim mamul maliyetine ilk madde malzeme, direkt iş̧̧ilik ve genel üretim giderlerinin yanı sıra pazarlama satış dağıtım ve genel yönetim giderlerini de dahil ettiğini tespit etmişlerdir. Dolayısıyla işletme mamul maliyetine katılmayacak olan harcamaları da katarak metrekare maliyet tutarını yanlış hesaplandığı ortaya çıkmıştır.

Bilginer vd. (2017) teknokentlerde faaliyet gösteren işletmelerin aldıkları teşviklerin/hibelerin TMS 20 Standardı çerçevesinde muhasebeleştirilmesiyle 
ilgili çalışma yapmışlardır. Çalışmada, vergi idaresi ile sorun yaşamamak için alınan hibelerin muhasebeleştirilmesi konusunda gelir yaklaşımının tercih edilmesi öneri olarak verilmiştir. Ancak, bu konuda yaşanan tereddütlerin ortadan kaldırılması için, tüm hibe desteklerinin muhasebeleştirilmesi konusunda kesin bir yasal düzenleme yapılmalıdır sonucuna ulaşılmıştır.

Karasioğlu ve Kınalı (2017) işletmelerin aldıkları teşviklerin/hibelerin TMS 20 Standardı çerçevesinde nasıl muhasebeleştirileceği ve finansal tablolarda nasıl yer alacağına ilişkin örnek uygulamalarda bulunmuşlardır.

Ertaş vd. (2017) tarımsal faaliyette kullanılan varlıklar için sağlanan teşvikleri TMS 20 ve TMS 41 kapsamında muhasebe kayıtlarını yapmışlardır. Çalışmada, teşvikin varlık maliyetinden indirilmeyip ertelenmiş gelir olarak kaydedilmesi finansal tablolarda hem varlığın elde edilme değeri hem de varlığa ilişkin teşvik tutarlarını bir arada göstereceği için daha bilgilendirici bir yöntem olduğu görülmüştür. Bununla birlikte uluslararası standartlarla uyumlu Türkiye Muhasebe Standartları'nın kabul edilmesiyle Tekdüzen Hesap Planında bir uyarlama yapılması zorunluluğu ortaya çımıştır.

Onocak ve Çukacı (2018) devlet teşviklerinin TMS 20, BOBİ FRS ve MSUGT'de yer alan düzenlemeleri dikkate alarak muhasebe kayıt örneklerine yer vermişlerdir. Söz konusu üç düzenleme arasındaki konuya ilişkin benzerlikler ve farklılıklar ortaya konulmaya çalışılmıştır.

Küçük (2018) teşvik kapsamında kullanılan kredilerin BOBİ FRS çerçevesinde muhasebe kayıtlarını yapmıştır. Çalışmada konuya ilişkin olarak iki farklı kayı̈ önerisinde bulunulmuşstur.

Yapılan literatür taramasından da görüleceği üzere maden işletmelerinde teşvik uygulaması ile ilgili birçok çalışma yapıldığı tespit edilmiştir. Ancak, faaliyette olan bir maden işletmesinin yatırım teşvik belgesi alınmasından başlanılarak muhasebe kayıtlarına yer verilmesi ve yatırım indiriminden yararlanıp yararlanmayacağının belirlenmesine yönelik çalışmaya pek rastlanmamıştır. Bundan sonra yapılacak olan çalışmalara yol göstermesi adına böyle bir araştırmaya ye verilmiştir.

\section{TEŞVİK UNSURLARININ MUHASEBE KAYIT ÖRNEKLERI}

Çalışmanın bu kısmında, yatırım teşvik belgesi kapsamında yatırım harcaması yaparak yatırım indirimi istisnalarından yararlanan bir krom madeni işletmesi uygulaması muhasebe kayıt örnekleri ile ele alınmıştır. Bu kapsamda, işletmede yapılması gerekli olan yatırım teşvik belgesinin alınmasından başlanılarak yapılması gereken muhasebe kayıtları, teşvik kapsamında alınan makinelerin 


\section{Kısakürek - S. Elden Ürgüp - M. Tatlı Türkive'de Maden İsletme...}

satılması, yatırım teşvik tamamlama vizesi aldıktan sonra yapılması gerekli olan işlemleri ve hesaplamaları örnekler yardımıyla açıklanmıştır.

\section{İlk Alım Kaydı}

Örnek Uygulama 1: Firma yatırıma başlamış ve ilk olarak kazı ve taşıma işlerinde kullanmak üzere 1 adet ekskavatör, 1 adet kamyon ve 1 adet yükleyiciyi kiralamıștır. Yatırımcı firma kiralama sözleșmesi sonunda iș makinelerini kendi adına alacaktır. İş makineleri yerli yatırım teşvik kapsamında olduğundan ilgili dokümanlar finansal kiralama şirketine gönderilmiş ve finansal kiralama şirketi tarafından onaylatılmıştır. Toplam kiralama tutarı 500.000 Euro olup, Euro kuru sözleşme tarihinde 3,00 TL'dir. Kiralamanın TL karşılığ 1 ise 1.500.000 TL'dir. Yatırımcı firmanın teşvik kapsamında KDV muafiyeti olduğundan kira süresi boyunca KDV ödemeyecektir. Yatırımcı firma kira ödemelerini 5 taksitini ilk yıl, kalan 5 taksitini ikinci y1l ödemek suretiyle 10 eşit taksitte, her bir taksiti 55.000 Euro olarak leasing kiralama şirketinin leasing kiralama sözleşme faturası düzenlenmesine istinaden ödeyecektir. Bu işlemden sonra yapılması gereken muhasebe kayıtlar sırasıyla aşağıdaki gibidir.

İlk Alım Kaydı

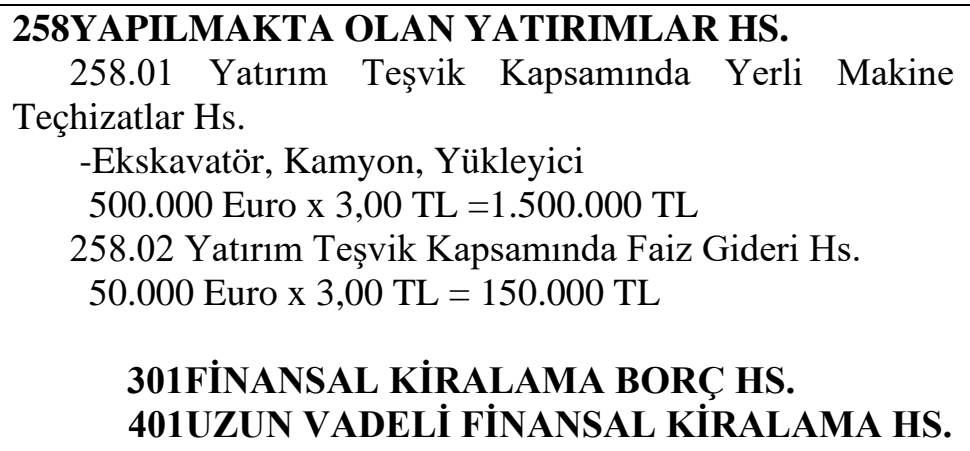

Teşvikli Finansal Kiralama Alım Kaydı

Ödeme tarihinde kur 3,10 TL olmuştur. Bu kur üzerinden yapılacak ödeme finansal kira ödeme kaydı aşağıdaki gibi olacaktır.

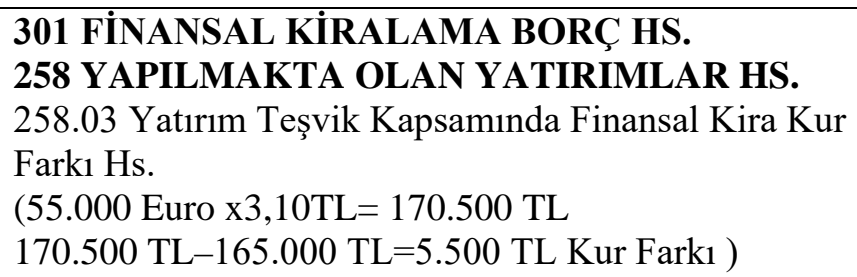

165.000
5.500


HS.

\section{DİĞER ÇEŞiTLII BORÇLAR}

336.01 A Finansal Kiralama Şti. Hs.

Finansal Kira Faturası Alım Kaydı

Yukarıdaki kayda ilişkin kur farkından oluşan kambiyo zararı yatırım teşvik tamamlama vizesi alana kadar yapılmakta olan yatırımlar hesabında izlenir. Tamamlama vizesi alındıktan sonra kur farkı ilgili 646-656 KAMBIYYO KARI/ZARARI hesabında izlenir. Yatırım teşvik kapsamında finansal kiralama yoluyla alınan iş makineleri finansal kira sözleşmesi sonunda finansal kiralama şirketi tarafından kiracı firmaya devri yapıldığında bu makine ve ekipmanları alım tarihinden itibaren 5 yıl boyunca satılamaz ve başka yerdeki yatırımlarda kullanılamaz. 5 yıl süre tamamlandıktan sonra İş Makineleri satılabilir ${ }^{2}$. Aykırı bir işlem yapılması durumunda ilgili bakanlık tarafından yatırım teşvik kapsamındaki destek tutarı geri alınır.

\section{Teşvik Kapsamında Alınan Makinelerin Satılması}

Teşvik kapsamında alınan maddi duran varlıkların satılması durumu aşağıdaki örnekle ele alınmıştır.

Örnek Uygulama 2: Teşvik kapsamında alınan İş Makineleri 5 yıl sonra $300.000 * \% 18 \mathrm{KDV}$ peşin satılmıştır. İş Makinesinin kayıtlı değeri 500.000 * olduğu ve birikmiş amortisman 300.000 " olduğu varsayılmıştır.

Yatırım Teşvikli İş Makineleri Satış Muhasebe Kaydı

\begin{tabular}{|c|c|c|}
\hline 100 KASA HS. & 354.000 & \\
602 DİĞER GELİR HS. & & 300.000 \\
\hline
\end{tabular}

\footnotetext{
2“Beş yıllık süreyi doldurmamış makine ve teçhizatın tamamlama vizesinin yapılıp yapılmadığına bakılmaksızın izinsiz satılması veya satılmasına sebebiyet verilmesi halinde konu hakkında en kısa sürede Bakanlığa bilgi verilmesi gerekir. Bu durumda, satışı yapılan makine ve teçhizat ile ilgili tahsil edilmeyen gümrük vergisi ve KDV ile varsa indirimli kurumlar vergisi veya gelir vergisi uygulanmak suretiyle yararlanılan destekler ilgili mevzuat çerçevesinde geri alınır. Satış dolayısıyla yatırım tutarında meydana gelen azalma nedeniyle kullanılabilecek azamî kredi tutarında azalma oluşması durumunda ise fazladan kullanılan krediye tekabül eden faiz desteği ile tahsil edilmeyen Kaynak Kullanımını Destekleme Fonu kesintileri ilgili mevzuat çerçevesinde geri alınır." İfade edilmiştir. Bu konu 2012/3305 Sayılı Yatırımlarda Devlet Yardımları Hakkında Karar Ve 2012/1 Sayılı Tebliğ.
} 
M. Kısakürek - S. Elden Ürgüp - M. Tatlı Türkive'de Maden İșletme...

\begin{tabular}{|c|c|c|}
\hline $\begin{array}{l}\text { 391 HESAPLANAN KDV HS. } \\
257 \text { BİRIKMMIŞ AMORTISMAN HS. } \\
\text { 623 DİĞER SATIŞLARIN MALIYETİ HS. } \\
\text { 253 TESİS MAKİNE CİHAZLAR } \\
\text { HS. } \\
\text { 253.01 Yatırım Teşvik İş Makinesi Hs. } \\
\text { Yatırım Teşvik Kapsamında Alınan İş Makinesi Satış } \\
\text { Kaydı }\end{array}$ & $\begin{array}{l}300.000 \\
200.000\end{array}$ & 500.000 \\
\hline
\end{tabular}

KDV'deki son yıllardaki değişikliklerden dolayı satışların ve gelirlerin gelir tablosuna şeffaf bir şekilde yansıtılması için bu şekilde kayıt yapılmıştır.

Örnek Uygulama 3: Yatırımcı firma tesis binası inşaatı ile ilgili olarak kum, çimento, tuğla, briket, demir, boya, hazır beton ve işçilik için $750.000 \mathrm{TL}+\% 18$ KDV fatura düzenlemiştir. Yapılan bu harcamaların muhasebe kaydı aşağıdaki gibidir. Yatırım teşvik belgesini çıkarılırken bakanlığa sunulan makine teçhizat listesi dışında alınan bina inşaatı için gerekli benzeri alımlarda KDV muafiyeti bulunmamaktadır. Dolayısıyla alımla ilgili yapılan harcamanın kaydı aşağıdaki biçimde olacaktır.

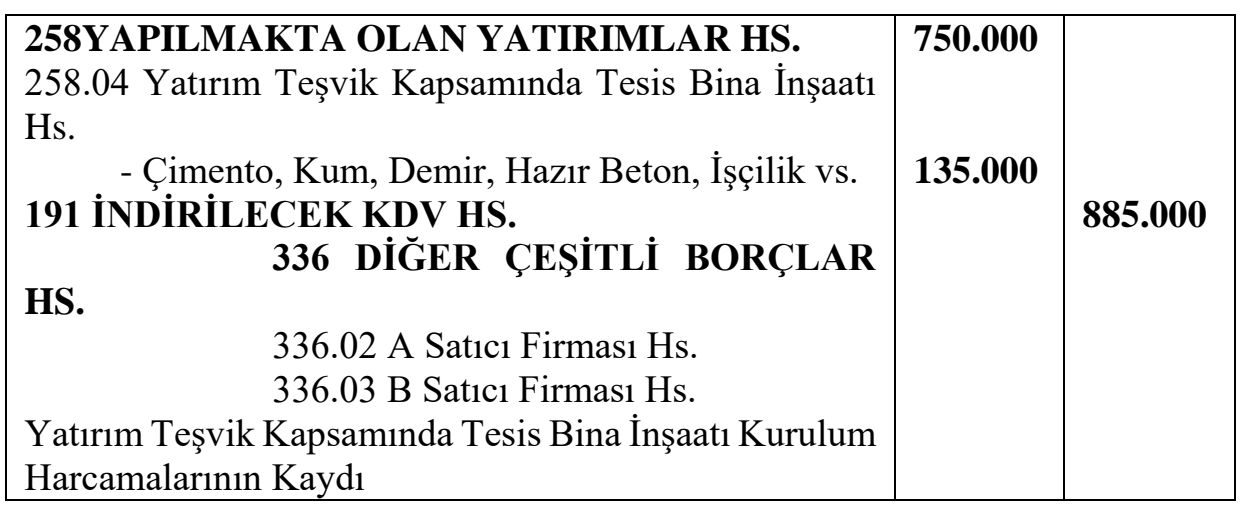


Örnek Uygulama 4: Yatırımcı firma madenin işlenmesi için yurtdışından makine teçhizat ekipman ithalatı yapmıştır. KDV ve gümrük muafiyeti için yatırım teşvik belgesi listesi gümrük ticaret bakanlığı tarafından onaylatılmıştır. Makine ekipman bedeli 500.000 USD'dir. Makine ekipmanların gümrüğe geldiğindeki USD kuru 2,00TL'dir. Makinelerin “ karşılığ1 1.000.000 TL'dir. Firma KDV muafiyet yazısı olduğu için makinelerin ithalat KDV'si ve gümrük vergisinden muaf tutulmuş ve herhangi bir ödeme yapılmamıştır. Firma makinelerin ithalatı için 10.000 USD karşılığ 20.000 TL navlun ücreti ve 10.000 TL gümrükleme tutarını nakit olarak ödemiştir. Örnek 4'e ilişkin muhasebe kayıtları aşağıdaki gibidir.

Yatırım Teşvik Kapsamında Tesis Bina Kurulumu İnşaatı Muhasebe Kaydı

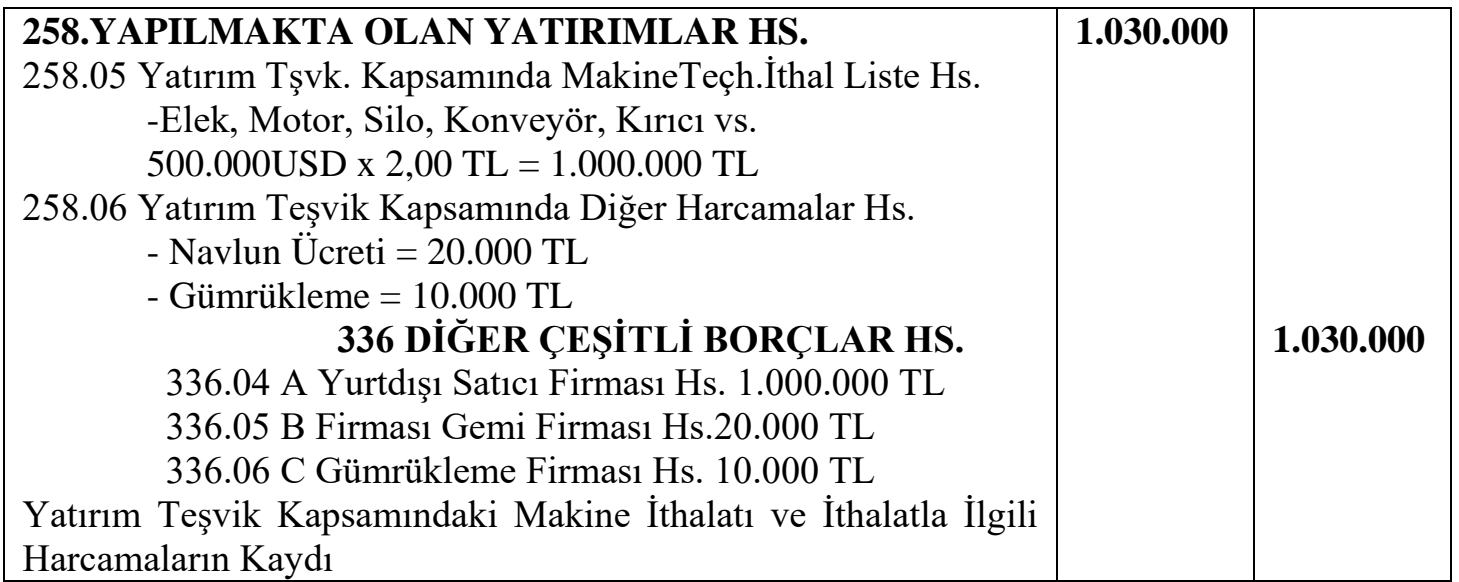

Örnek Uygulama 5: Yatırımcı firma tesisin eksik makineleri için 500.000 TL'lik yerli listedeki değirmen, sallantılı masa, bant vs. makine teçhizat ekipman alımı yapmıştır. Makine ekipmanlar yerli ve ithal listede olduğu için ${ }^{3}$ KDV ödenmemiştir. Yatırım teşvik belge aslı satıcı firmaya gönderilerek alımı yapılan ilgili makine ekipman listesi satıcı firma tarafından onaylanmıştır. İlgili muhasebe kaydı aşağıdaki gibidir.

Yatırım Teşvik Kapsamında Yerli Listedeki Makine Teçhizat Alımı Muhasebe Kayd1,

258YAPILMAKTA OLAN YATIRIMLAR HS. 258.01 Yatırım Teşvik Kapsamında Yerli Mak.Teçh. Hs.

${ }^{3}$ Bakanlığın onayladığı yerli ve ithal liste dışında kalan bütün harcamaların KDV muafiyeti yoktur. 
M. Kısakürek - S. Elden Ürgüp - M. Tatlı Türkive'de Maden İșletme...

- Değirmen, Sallantılı Masa, Bant vs.

336 DİĞER ÇEŞiTLİ BORÇLAR HS.

336.02 A Satıc1 Firmas1 Hs.

Yatırım Teşvik Kapsamında Makine Teçhizat Yerli Liste

Alım Kayd 1

Yukarıdaki kayıt yatırımcı firmanın yapması gereken kayıttır. Buna karşılık satıc1 firma yatırımc1 firmanın KDV muafiyet yazısına istinaden hesaplanan KDV'sini tahsil edememiştir. Bu işlem doğrultusunda satıcı firmaya makine teçhizat imalatı veya alımında maliyetine yüklendiği KDV'nin vergi dairesince iadesi mümkündür. Satıcı firma ilgili satışın gerçekleştiği KDV döneminde, KDV beyannamesinde yer alan istisnalar, iade hakkı doğuran işlemler ve ihraç kaydıyla teslimler başlığı altında yer alan Tam İstisna kapsamına giren işlemler kısmında teslim tutarı ve yüklendiği KDV tutarını göstermek şartıyla nakden veya mahsuben KDV iadesini alabilir. Satııı firmanın satış muhasebe kaydı da aşağıdaki gibidir.

\begin{tabular}{|l|l|l|}
\hline 120.ALICILAR HS. & $\mathbf{5 0 0 . 0 0 0}$ & \\
120.01 A Alıcı Firma Hs. & & \\
$\quad \begin{array}{l}\text { 600 YURTíçi SATIŞLAR HS. } \\
\text { 600.01 Yatırım Teşvikli Mal Satışı Hs. }\end{array}$ & & $\mathbf{5 0 0 . 0 0 0}$ \\
Yatırım Teşvikli Malların Satış Kaydı & \\
\hline
\end{tabular}

Örnek Uygulama 6: Yatırımcı firma örnek 3 ve örnek 4 teki yatırım teşvik kapsamında alınan makine ve teçhizatların finansmanını sağlamak için A bankasından 1.500 .000 "'lik 3'er aylık dönemlerde (12 eşit taksitte) 3 yılda ödemek üzere yatırım teşvik destekli kredi kullanmıştır. Faiz oranı \%17,16 ve bakanlıkça belirlenen teşvikli faiz desteği 5 puan değerindedir. Teşvikli çekilen krediye ilişkin bilgiler aşağıdaki tabloda gösterilmiştir.

Tablo 3. Yatırım Teşvikli Toplam Ödenecek Kredi Ödeme Tablosu

\begin{tabular}{|l|l|l|l|ll|}
\hline Anapara & Faiz Tutar1 & BSMV \%5 & $\begin{array}{l}\text { Toplam } \\
\text { Ödeme }\end{array}$ & $\begin{array}{l}\text { Bakanlık Faiz } \\
\text { Desteği }\end{array}$ \\
\hline 1.500 .000 & $486.041,10$ & $24.302,06$ & $2.010 .343,16$ & $141.632,38$ & \\
\hline
\end{tabular}

Yatırım teşvikli kredilerde sadece faiz tutarı teşvik kapsamına girmektedir. Bakanlık Banka Sigorta Muamele Vergisi (BSMV) tutarını yatırım teşvik kapsamına dahil etmemektedir. Ayrıca bakanlıkça ödenecek olan faiz tutarı da teşvik kapsamında yatırım maliyetine katılmamaktadır. Bakanlıkça iade edilecek tutar yatırımcı firma için gelir olmaktadır. Bu iade edilecek tutar toplam faizden 
düşülmemesi durumunda devlet hazinesi zarara uğratılmış olur. Olması gereken hesaplamalar ve muhasebe kayıtları aşağıdaki gibidir.

\section{Faiz Desteği Hesaplama:}

Faiz desteği puanı: 5 Puan

Kredi faiz oranı: 17,16

Faiz desteği oranı hesaplama:(5 / 17,16)x 100=\% 29,14

$486.041,10 \times$ \% $29,14=141.632,38 \mathrm{TL}$

Yatırım Teşvik Kapsamına Alınacak Faiz Tutarı:

486.041,10 TL $-141.632,38 \mathrm{TL}=344.408,72 \mathrm{TL}$ 'dir.

Gelecek aylar ve yıllar itibariyle gider dönüştürülecek giderler $=$ BSMV

+ Bakanlık faiz desteği Tutarı ${ }^{4}$

$=24.302,06+141.632,38=165.934,44$

3 y1l için de gidere dönüştürüleceğinden her yıla düşen pay ise;

$165.934,44 / 3=55.311,48$

Yatırım Teşvik Kapsamında Çekilen Teşvikli Kredinin Muhasebe Kaydı,

102 BANKALAR HS.
102.01 A Bankası Mevduat Hs.
258 YAPILMAKTA OLAN YATIRIMLAR HS.

258.07Yatırım Teşvik KapsamındaKredi Faiz Gideri 180GELECEK AYLARA AITT GIDERLER HS.

180.01 1.Y1l Faiz Gideri Hs.

Cari Dönem Giderleştirilecek Tutar=

55.311,48 TL

280GELECEK YILLARA AIT GIDERLER HS.

280.01 2.Y1l Faiz Gideri Hs.

2. Y1l Giderleştirilecek Tutar $=55.311,48 \mathrm{TL}$

280.02 3.Y1l Faiz Gideri Hs.

\begin{tabular}{|l}
1.500 .000 \\
$344.408,72$
\end{tabular}

$55.311,48$

$110.622,96$

${ }^{4}$ Bakanlık kredi faiz desteği iadelerini kredi taksit tutarı ödendikten sonra yapmaktadır. Bundan dolayı kredi faizlerini ilgili dönemlerde gider kaydedilir.Dolayısıyla önce gider yazılır. Sonra bakanlık iade yaptığında iade tutarı gelir yazılır. 
M. Kısakürek - S. Elden Ürgüp - M. Tatlı Türkiye'de Maden İsletme...

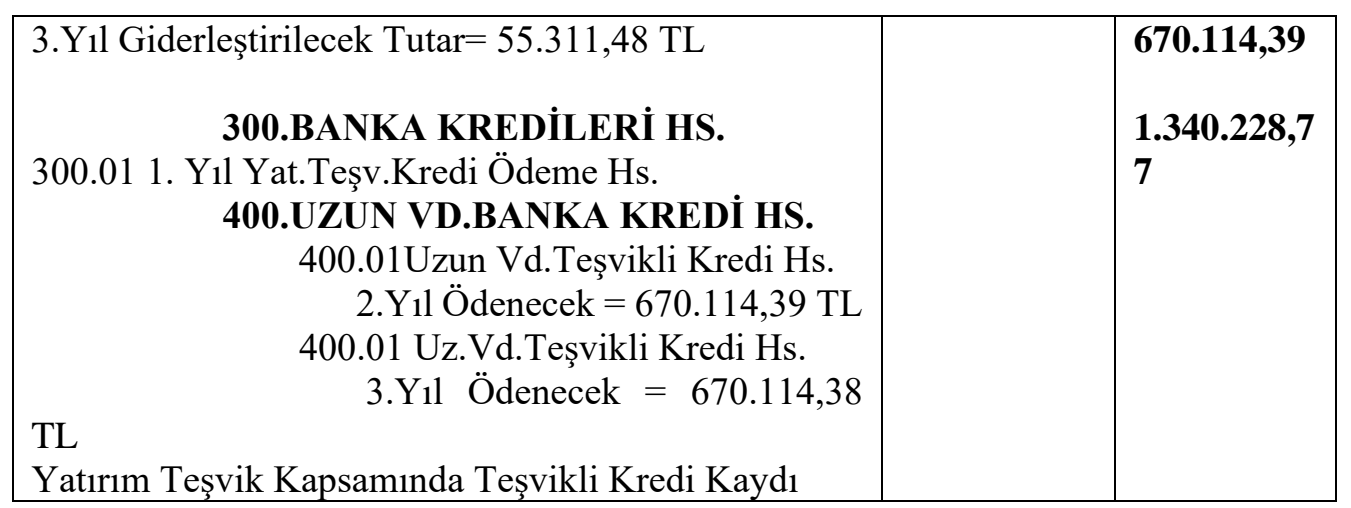

Kaydı yapılan yatırım teşvik kredisi taksitleri ödendiğinde yapılması gereken muhasebe kaydı aşağıdaki gibidir.

Yatırım Teşvik Kapsamında Çekilen Teşvikli 3 yıl vadeli 12 Taksit Ödemeli Kredinin Muhasebe Kayd,,

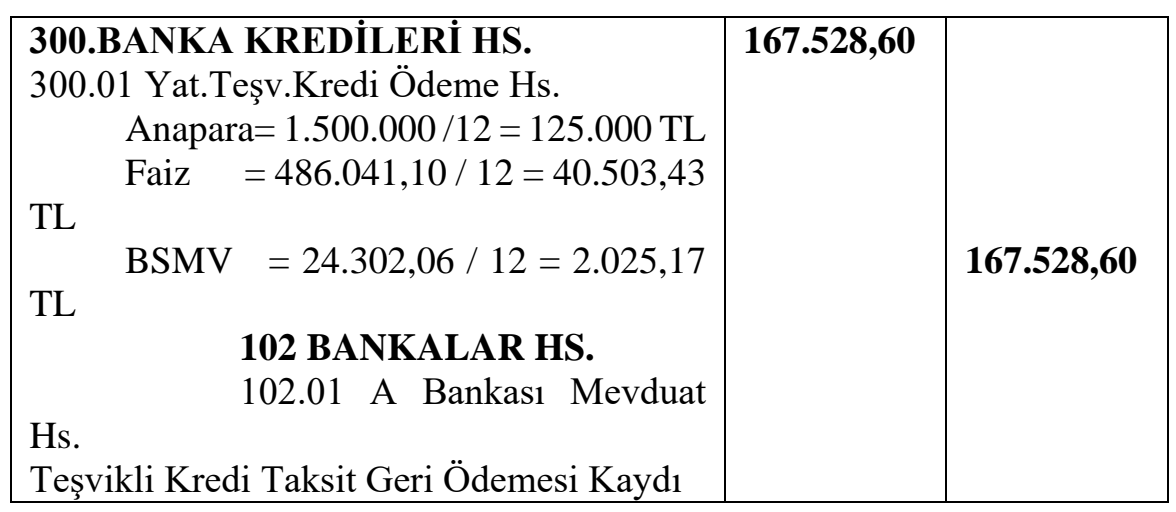

Bakanlıkça yatırımcı tarafından ödenen ilk taksit geri ödemesinin destek tutarı banka tarafından iadesi yapılmıştır. İlk taksit iade hesaplama ve muhasebe kaydı aşağıdaki gibidir.

\section{Bakanlık hesaplanan ve banka tarafindan ödenecek tutar:}

Faiz $=40.503,43 \mathrm{TL}$

40.503,43 TL x \%29,14 = 11.802,70 TL

Yatırım Teşvik Kapsamında Çekilen Kredinin Bakanlık Tarafından Faiz İadesi Ödeme Muhasebe Kayd1, 


\begin{tabular}{|c|c|c|}
\hline 102 BANKALAR HS. & $\mathbf{1 1 . 8 0 2 , 7 0}$ & \\
102.01 A Bankası Mevduat Hs. & & \\
649 FAALIYETLERDEN OLAĞAN & & $\mathbf{1 1 . 8 0 2 , 7 0}$ \\
GELİR VE KÂRLAR HS. & & \\
649.01 Yat.Teşv.Kaps.Faiz Gelir Hs. & & \\
Teșvikli Kredi Faiz Geliri Muhasebe Kayd 1 & & \\
\hline
\end{tabular}

Yatırım teşvik kapsamında kullanılan kredilerin toplam tutarı bakanlıkça onaylanan kredi üst limitini geçemez. Faiz desteği en az bir yıl vadeli krediler için uygulanır. Bölgesel desteklerden yararlanacak yatırımlarda, faiz desteği uygulamasına esas olacak kredi tutarı, sabit yatırım tutarını \% 70'ini geçemez. Faiz desteği belirlenen kapsam dâhilinde azami ilk kredi kullanım tarihinden itibaren 5 yıl süreyle uygulanır. Eğer belirlenen tutarlarda artış ya da azalış olursa yatırımcı firma yatırım teşvik belgesini revize etmesi gerekmektedir. Yatırımcı firma tarafından yapılan herhangi uyumsuzluk halinde ilgili bakanlığın verdiği destek geri alınır (Yatıımlarda devlet yardımları hakkında kararın uygulanmasına ilişkin tebliğ(Tebliğ no: 2012/1)'de değişiklik yapılmasına dair tebliğ (Tebliğ No: 2017/1).

Örnek Uygulama 7: Yatırımcı firma yatırım dönemi içinde teşvik kapsamında yerli ve ithal listedeki makine teçhizat ve ekipmanların çalışması ve kurulması için gerekli olan yardımcı malzeme olarak toplamda $250.000 "+\% 18$ KDV değerinde pompa, jeneratör, yedek parça, pano vs. almıştır. Bu alınan ekipmanların tamamı yatırım maliyeti olarak kaydedilmiştir. Yapılması gereken muhasebe kaydı aşağıdaki gibidir.

Yatırım Teşvik Kapsamında Alınan Diğer Harcamalar Muhasebe Kaydı,

\begin{tabular}{|l|l|l|}
\hline 258.YAPILMAKTA OLAN YATIRIMLAR HS. & $\mathbf{2 5 0 . 0 0 0}$ & \\
$\begin{array}{l}\text { 258.06 Yatırım Teşvik Kapsamında Diğer Harcalar Hs. } \\
\text { - Pompa, Jeneratör, Yedek Parça, Pano vs. }\end{array}$ & $\mathbf{4 5 . 0 0 0}$ & \\
191 İNDİRILECEK KDV HS. ${ }^{6}$ & & $\mathbf{2 9 5 . 0 0 0}$ \\
\hline
\end{tabular}

5 Devlet teşviklerini gelir kaydederek vergi matrahına ilave edilir. $\mathrm{Bu}$ kapsamda kullanılan kredinin ödenen faizi öncesinde giderleştirilmektedir. Destek iadesi olduğunda gelir yazıyoruz. Şekil olarak gider geliri götürüyoruz. Muhasebenin temel kavramlarına uygun kaydetmek için. (Dönemsellik, Tahakkuk esası)

${ }^{6}$ Bina inşaat ve diğer yardımcı malzemeler için KDV muafiyeti yatırım teşvik belgesi listesinde yer almamakla birlikte teşvik kapsamında toplam yatırım harcamalarına dâhildir. 
M. Kısakürek - S. Elden Ürgüp - M. Tatlı Türkive'de Maden İsletme...

HS.

\section{DİĞER ÇEŞİTLİ BORÇLAR}

336.02 A Satıc1 Firması Hs.

Yatırım Teşvik Kapsamında Diğer Harcamalar Kaydı

Örnek Uygulama 8: Yatırımcı firma yatırım dönemi içinde teşvik kapsamında yerli ve ithal listedeki makine teçhizat ve ekipmanların çalışması, kurulması ve yatırım bölgesine taşınması için toplamda $100.000 *$ + \% 18 KDV proje, mühendislik danışmanlık, nakliye ve montaj için harcamalar yapmıştır. Yapılması gereken kayıtlar aşağıdaki gibidir.

Yatırım Teşvik Kapsamında Alınan Diğer Harcamalar Muhasebe Kaydı,

\begin{tabular}{|c|c|c|}
\hline \multirow{3}{*}{$\begin{array}{l}\text { 258YAPILMAKTA } \\
\text { YATIRIMLAR HS. } \\
\text { 258.06Yatırım Teşvik Kaps. Diğer Harcalar } \\
\text { Hs. }\end{array}$} & \multirow[t]{3}{*}{100.000} & \multirow{7}{*}{118.000} \\
\hline & & \\
\hline & & \\
\hline $\begin{array}{l}\text { - Proje, Müh.Danışmanlık, Nakliye, } \\
\text { Montaj Gideri }\end{array}$ & \multirow{4}{*}{18.000} & \\
\hline $\begin{array}{c}191 \text { İNDİRİLECEK KDV HS. } \\
336 \\
\text { DİĞER }\end{array}$ ÇEŞITLI & & \\
\hline $\begin{array}{l}\text { BORÇLAR HS. } \\
\text { 336.02 A Satıc1 Firmas1 Hs. }\end{array}$ & & \\
\hline $\begin{array}{lrl}\text { Yatırım Teşvik } & \text { Kapsamında } & \text { Diğer } \\
\text { Harcamalar Kaydı } & & \end{array}$ & & \\
\hline
\end{tabular}

\section{Tamamlama Vizesi Alındıktan Sonra Yapılacak İşlemler}

Yukarıdaki örneklerle bahsedilen işlemler yatırıma başlanılan ilk tarih ile tamamlama vizesi alınana kadar olan yatırımcı firmanın yapması gereken işlemleri ve muhasebe kayıtları gösterilmiştir. Yatırımcı firma yatıım teşvik belgesi kapsamında liste ve kapsam dahilinde tüm yatırımlarını tamamlar ve maden ocağını ve tesisi üretime hazır vaziyete getirir. Daha sonra yatırım teşvik tamamlama vizesi için gerekli dosyaları ve belgeleri mevzuata uygun şekilde hazırlayarak ilgili bakanlığa başvurur. Bakanlık dosyayı kabul ettikten sonra yatırımını yerinde görmek için bakanlık memurları yatırımın olduğu maden ocağında incelemeler yapar. Bakanlık memurları ilgili yatırımı proje, muhasebe kayıtları ve makinelerin gerçekte alınıp alınmadığını tespit çalışmasından sonra tamamlama vizesi alınır. Bakanlık memurları bazı harcamaları teşvik kapsamında saymayabilir. Yatırımcı firma için yukarıdaki örnekleri baz alarak kabul edilen toplam yatırım maliyeti Tablo 4'teki gibidir. 
Tablo 4. Yatırım Maliyeti Tablosu

\begin{tabular}{|c|c|c|c|}
\hline \multicolumn{4}{|c|}{ TOPLAM YATIRIMA İLIŞKİN KABUL EDİLEN YATIRIM TUTARI } \\
\hline \multicolumn{2}{|c|}{ Toplam Sabit Yatırım (TL): 4.680 .000} & \multicolumn{2}{|c|}{$\begin{array}{l}\text { Yatırımın Finansmanı (TL): } 4.680 .000 \\
\text { TL }\end{array}$} \\
\hline I. Arazi-Arsa & & I. Öz Kaynaklar: & $1.680 .000 \mathrm{TL}$ \\
\hline II. Bina-İnşaat: & $750.000 \mathrm{TL}$ & II. Yabanc1 Kaynaklar: & \\
\hline III. Makine ve Teçhizat: & & a. İç Kredi: & 1.500.000 TL \\
\hline a. İthal Makine ve Techizat: & $1.000 .000 \mathrm{TL}$ & b. Diș Kredi: & \\
\hline b. Yerli Makine ve Teçhizat: & $2.000 .000 \mathrm{TL}$ & $\begin{array}{l}\text { c. Döviz / Dövize } \\
\text { Endeksli Kredi: USD } \\
\text { Finansal Kiralama }\end{array}$ & 1.500.000TL \\
\hline IV. Diğer Harcamalar: & & & \\
\hline a. Kur Fark1: & $50.000 \mathrm{TL}$ & & \\
\hline b. Faiz Gideri: & $500.000 \mathrm{TL}$ & & \\
\hline 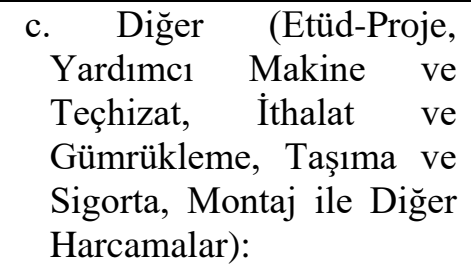 & $380.000 \mathrm{TL}$ & & \\
\hline V. Toplam: & $4.680 .000 \mathrm{TL}$ & III. Toplam: & 4.680.000TL \\
\hline
\end{tabular}

Örneğe ilişkin Ekonomi Bakanlığı toplam yatırım tutarını 4.680.000 TL kabul etmiş varsayılmıştır. Yatırımcı firma 5.bölgesine dahil olmaktadır. Toplam yatırıma ilişkin diğer destek unsurları aşağıdaki gibidir.

Vergi indirimi desteği kurumlar vergisi desteği toplam yatırımın $\% 40$ ve vergi karşılama oranı ise \%80'dir.

Sigorta Primi İşveren Desteği 7 Y1l olarak toplam yatırımın \%35'ni geçmemek kaydıyla ve mevcut istihdam 30 kişi ve ilave istihdam olarak 30 kişi olarak belirlenerek kabul etmiştir.

Yukarıdaki diğer hususlara ilişkin yatırımcı firmanın yapması gereken işlemler ve muhasebe kayıtları aşağıdaki gibidir.

\section{Vergi İndirimi Örnek Hesaplama}

Toplam yatırıma katk1 oran $1 \% 40$ 'dır.

Toplam Gerçekleşen Yatırım Harcaması x Toplam Yatırıma Katkı Oranı 


\section{Kısakürek - S. Elden Ürgüp - M. Tatlı Türkive'de Maden İsletme...}

$=4.680 .000 \mathrm{TL} \times \% 40$

$=1.872 .000$ TL'dir.

\section{Vergi Karşılama Oranı Örnek Hesaplama ve Uygulama}

Kurumlar Vergisi Oranı \%22, vergi karşılama oranı \%80'dir.

$=(0,22 \times 0,80) \times 100=\% 17,60$ Karşılama oranı

$=0,22-0,1760=\% 4,40 \mathrm{KV}$ Oran 1

Yatırımcı firma teşvik belgesi kapsamında ödediği vergi tutarı belirlenen 1.872.000 TL tutarına ulaşıncaya kadar vergi indiriminden faydalanabilir. Toplam yatırım tutarına ulaşınca normal vergi oranından vergilendirilecektir. Yatırım teşvik belgesine sahip firmalar vergi indiriminden tamamlama vizesi yapıldıktan sonra vergi teşvikinden faydalanmak için beklemeyebilir. Toplam gerçekleşen yatırım toplam sabit yatırımın tutarının \%10'una ulaşınca vergi indiriminden faydalanabilir. Kurumlar vergisi indirimi bilgilerini ve tutarların ilgili kurum geçici vergi ve kurumlar vergisi beyannameleri hesap dönemlerinde kurumlar vergisi beyannamesinde indirimli kurumlar vergisi tablosunda belirtmek zorundadır. Ayrıca her hesap dönemi sonunda belirlenen yeniden değerleme oranları doğrultusunda kalan yatırıma katkı tutarı kadar yeniden değerlemeye tabi tutulur. Yatırımcı firma hak kazandığı toplam yatırıma katkı tutarını nazım hesaplarda takip etmesinde fayda vardır ve her hesap dönemi sonunda kullanmış olduğu yatırıma katkı tutarını bu nazım hesaplardan azaltmasında tutarın takibi açısından önemlidir. Olması gereken kayıt aşağıdaki gibidir.

Toplam Yatırıma Katkı Tutarı Muhasebe Kaydı,

\begin{tabular}{|l|l|l|}
\hline 940 YATIRIM İNDİRİII HS. & $\mathbf{1 . 8 7 2 . 0 0 0}$ & \\
940.01 XX Belge Nmrl. Yatırıma Katkı Tutarı Hs. & & \\
941 YATIRIM İNDİRİMI KARŞILIK HS. & & $\mathbf{1 . 8 7 2 . 0 0 0}$ \\
941.01 XX Belge NL Yatırıma Katk1 Tutarı & & \\
Karş.Hs. & & \\
Komple Yeni Yatırıma Katkı Tutarı Kayd 1 & \\
\hline
\end{tabular}

Örneğe göre;

Vergi Matrahı: 1.420.454,55 TL

Vergi Oran1 \%22: 312.500 TL ( $1.420 .454,55$ TL x \%22 ) 
Yatırıma Katk1 Oran1 \%17,60 $=1.420 .454,55$ x 17,60 $=250.000 \mathrm{TL}$

Kurumlar Vergisi $\% 4,40=1.420 .454,55 \times$ x 4,4 $=62.500$ TL çıkan kurumlar vergisi

Ödemesi ve tahakkuk kaydı normal kurumlar vergisi tahakkuk ve ödeme kaydıyla farkı bulunmamaktadır.

Yatırımcı firma X Kurumlar vergisi hesap döneminde 250.000 TL vergi indiriminden faydalanmıştır. İzleyen hesap döneminde yapılacak muhasebe kaydı aşağıdaki gibidir.

X Hesap Döneminde Yararlanılan Yatırıma Tutarı Muhasebe Kaydı,

\begin{tabular}{|c|c|c|}
\hline $\begin{array}{l}\text { 940 YATIRIM İNDİRIMI HS. } \\
\text { 940.01 XX Belge NL Yatırıma Katkı Tutarı Hs. } \\
\text { 941 YATIRIM İNDİRIMI KARŞILIK } \\
\text { HS. } \\
\text { Karş. } \\
\text { X Hesap Döneminde Yararlanılan Yatırıma Katkı Tutarı } \\
\text { Kaydı }\end{array}$ & 250.000 & 250.000 \\
\hline
\end{tabular}

\section{Sigorta Primi İşveren Desteği}

Örnek Uygulama 9:Bakanlık tarafından yatırımcıya verilen işveren desteği primi 30 kişidir. Sigorta Primi İşveren Hissesi ve Sigorta Primi desteklerinin uygulanmasına, teşvik belgesinin tamamlama vizelerinin yapılmasının ardından, destekten yararlanacak olan işletmelere ilişkin bilgilerin Bakanlıkça Sosyal Güvenlik Kurumuna elektronik ortamda bildirildiği tarihi takip eden aybaşından itibaren başlanılabilir. Destek teşvik belgesinde kayıtlı süre boyunca uygulanır. Ancak yine teşvik belgesi üzerinde kayıtlı azami prim tutarının aşılması halinde destek uygulamasına son verilir. İlgili desteğe ilişkin kanun maddesi 16322 sayılı kanun aktivasyonu yapılır. Sigorta primi işveren desteğinden faydalanan yatırımcı firmanın yapması gereken muhasebe kaydı aşağıdaki gibidir.

Ücret Bordrosu Kayd1,

\begin{tabular}{|c|c|c|}
\hline $\begin{array}{l}720 \text { DÍREKT İŞÇİLİK GİDERİ HS. } \\
720.01 \text { Brüt Isçilik Gideri Hs. = 40.000 TL } \\
720.02 \text { SGK Primi İşveren PayiHs. }=8.000 \\
\text { TL }\end{array}$ & 50.000 & 27.500 \\
\hline
\end{tabular}


M. Kısakürek - S. Elden Ürgüp - M. Tatlı Türkive'de Maden İsletme...

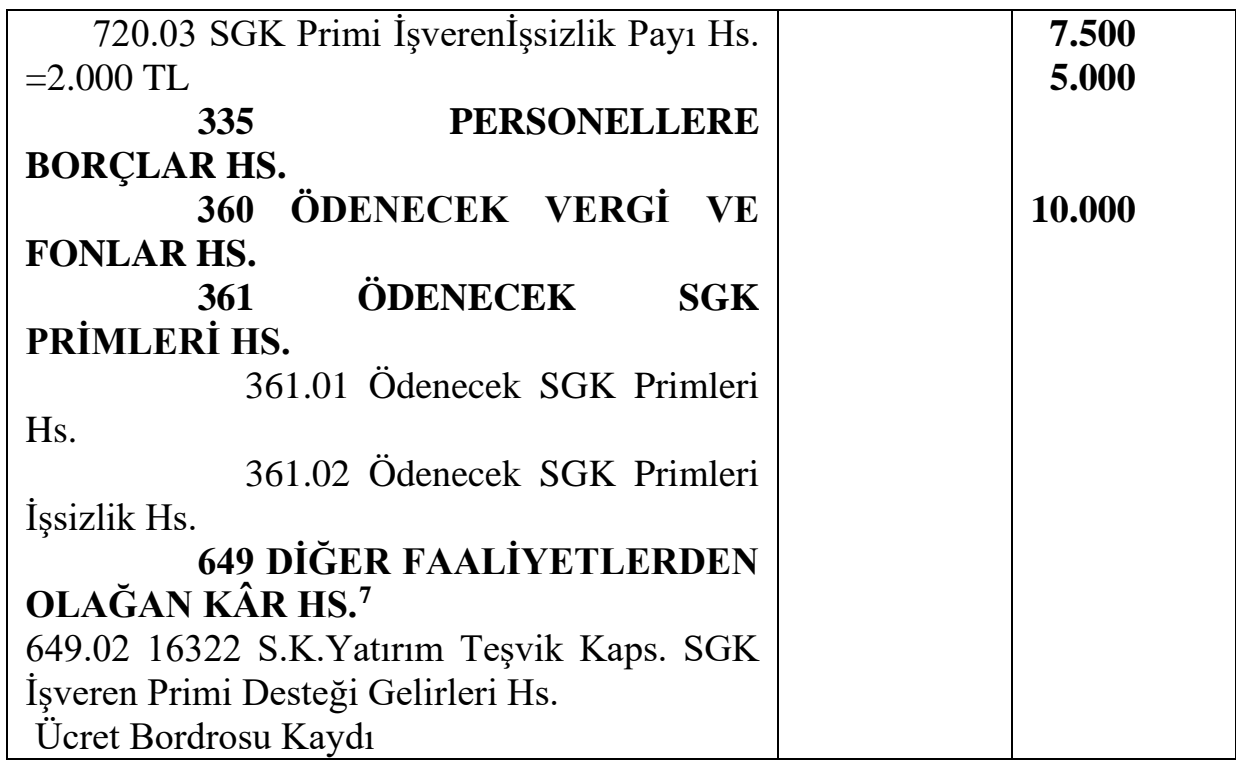

Yatırımcı firma teşvik uygularken uygulama esaslarına uymak zorundadır. Fazla ve yersiz faydalanılan teşvikleri Sosyal Güvenlik Kurumu teşvikleri yatırımc1 firmadan geri talep eder ve yatırımcı firmanın 1 yıl boyunca herhangi bir teşvikten faydalanmasına izin vermez.

\section{SONUÇ}

Türkiye'de üretilen maden ürünleri; inşaat, tarım, enerji sektöründe ve sanayide hammadde olarak tüketilmekte olup, ülkemiz ekonomisine ciddi katma değer sağlanmaktadır. Yani ana yatıım alanlarının temel girdilerini oluşturması, madencilik sektörünü gelişmişliğe katkı sıralamasında en önemli sektör haline getirmektedir. Türkiye, belli zenginlik ve kalitede olan maden kaynaklarını ihraç ederken; sanayisinin gerek duyduğu ve yurtiçi kaynaklardan yeterli miktar ve/veya kalitede üretemediği madenleri de ithal etmektedir.

Ülkemizde yatırımları desteklemek için yatırımcılara çok çeşitli teşvikler sağlanmakta ve teşvik sistemi sürekli olarak güncellenmektedir. Teşviklerle ilgili güncel düzenleme 19 Haziran 2012 tarihinde alınan 3305 sayılı "Yatırımlarda

\footnotetext{
${ }^{7}$ Yatııım teşvik kapsamında SGK işveren desteğinin tamamını teşvik olarak vermektedir. İşveren teşvikinde SGK primi işveren payı ile SGK primi işveren işsizlik payının tamamını teşvik kapsamında indirim yapılmaktadır. Örnekte 720 hesabında altında 8.000 $\mathrm{TL}+2.000 \mathrm{TL}=10.000 \mathrm{TL}$ toplamıdır.
} 
Devlet Yardımları Hakkında Karar" ile yürürlüğe girmiş; Kararın uygulanmasına ilişkin usul ve esaslar da 2012/1 sayılı Tebliğ ile yeni teşvik sistemi belirlenmiştir.

$\mathrm{Bu}$ çalışmada, maden sektöründe faaliyette bulunan krom maden işletmesinin yatırım teşvik belgesi kapsamında yatırım harcaması yaparak yatırım indirimi istisnalarından yararlanırken yapılması gereken muhasebe kayıtları örnekler yardımıyla incelenmiş̧ir. Diğer taraftan, aktif bir işletme tarafından bilgiler elde edildiği için çalışma konusu daha verimli bir şekilde ele alınarak somutlaştırılmıştır. Bu kapsamda, işletmenin yatırım teşvik belgesi alınmasından başlanılarak yapılması gereken muhasebe kayıtları, işlemlerle alakalı bilgiler ve hesaplamalar örnekler ile desteklenmeye çalışılmıştır.

Sonuç olarak işletmenin yatırım harcamaları teşvik kapsamında sayılabilmesi için yatırım harcamalarının ilk kayıtlarını duran varlıklarda yapılmakta olan yatırımlar hesabında takip edilmiş, ilgili yatırım harcamaları ve yatırım teşvik tamamlama vizesi aldıktan sonra yapılması gerekli olan işlemleri ve hesaplamaları Ekonomi Bakanlığının belirlediği kriterlere ve ilgili mevzuata uygun bir şekilde yapılmıştır. Böylece söz konusu işletmenin yatırım indiriminden yararlandığ tespit edilmiştir Ayrıca, işletmenin mevzuatta yer alan uygulama esaslarını benimsediği için işletmeden bilgi alacak olan karar alıcıları da yanıltmadığı sonucuna ulaşılmıştır.

Bu noktayla birlikte, bu çalışmanın ve literatürdeki benzer konulu çalışmalar incelendiği zaman, maden sektöründe faaliyette bulunan işletmelerin yatırım teşvik uygulamaları ile ilgili farklı muhasebe kayıtlarının yapıldı̆̆ görülmektedir. $\mathrm{Bu}$ farklılıkları giderebilmek adına aşağıdaki noktalar araştırmacılar ve konuyla ilgili karar mekanizmalarında yer alan yetkililere öneri olarak sunulmaktadır:

- İşletmelerin yatırım harcamalarının teşvik kapsamında sayılabilmesi için yatırım harcamalarının ilk kayıtlarını duran varlıklarda yapılmakta olan yatırımlar hesabında takip edebilir.

- Muhasebe kayıtlarını ilgili mevzuata göre kayıt altına almalıdırlar. Hesaplamaları ise; Ekonomi Bakanlığının belirlediği kriterleri baz alarak yapmalıdırlar.

- Güncel yatırım teşvik sistemleri ile ilgili yayınlanan tebliğler takip edilmeli, gerekli görüldüğü takdirde işletme personelini bu konuda yapılan eğitimlere göndermelidir. 
M. Kısakürek - S. Elden Ürgüp - M. Tatlı Türkive'de Maden İșletme...

- Çalışma sadece maden sektörü ile sınırlıdır. Farklı sektörleri de çalışmanın kapsamına dahil edilebilir ve böylece literatüre daha kapsamlı bir çalışma kazandırılabilir.

\section{KAYNAKÇA}

Acar, Durmuş- Dalğar, Hüseyin- Akın, Osman (2012);“Faaliyet Tabanlı Maliyetleme Uygulaması İle Hesaplanan Maliyetler İle Mevcut Maliyetlerin Karşılaştırılması: Mermer İşletmesi Örneği”, Muhasebe Bilim Dünyası dergisi, Cilt:14, Haziran, ss.1-28.

Bilginer, Mesut-Afşar, Alican- Akdoğan Zahide(2017),"Teknoloji Geliştirme Bölgelerini Yöneten Teknokent Anonim Şirketlerin Faaliyet Gelirlerinin Vergi Mevzuatı Açısından Değerlendirilmesi ve Alınan Hibelerin TMS 20'ye Göre Muhasebeleștirilmesi”, Journal Of SocialAndHumanitiesSciencesResearch, Vol.4, No: 15, ss. 2016-2025.

Buyruk, Ayşe Nur (2013), “Muhasebe Standartlarına Göre Maden Kaynaklarının Araştırılması, Değerlendirilmesi, Dekapaj İşlemleri ve Muhasebeleştirilmesi", TheJournal of Academic Social Science Studies, Vol. 6 No:3, Mart, ss. 77-90.

Coşkun, Sedat (2016), “Teşvik Kapsamında Elde Edilen Maddi Duran Varlıkların Muhasebe Standartları Kapsamında İncelenmesi”, İnsan ve Toplum Bilimleri Araştırmaları Dergisi Cilt: 5, Sayı: 7, ss. 2193-2207.

Çelik, Tarık Ziyad- Gerekli, İsa- Ertürk, Süleyman- Günay, Yahya- Bilginer Mesut (2015), "TMS 20 Devlet Teşviklerinin Muhasebeleştirilmesi ve Devlet Yardımlarının Açıklanması”, Kahramanmaraş Sütçü İmam Üniversitesi İktisadi ve İdari Bilimler Fakültesi Dergisi, Cilt:5, Sayı:2, ss. 293-304.

Demir, Fatma ve Çiftci, Yavuz (2017), “Maden İşletmelerinde Maliyet Muhasebesi Sistemi: Bir Mermer İşletmesinde Uygulama" Uluslar arası Sosyal Araştırmalar Dergisi Cilt:10, Say1: 49, Nisan, ss. 596-606.

Ertaş, Fatih Coşkun- Çidem, İbrahim- Çiğdem, Reşit(2017), “Tarımsal Teşviklerin TMS 20 ve TMS 41 Kapsamında İncelenmesi” Muhasebe Bilim Dünyası Dergisi; 19(3), ss. 577-591.

Gerekan, Bilal ve Gerekan, Bekar (2014), “Petrol Elde Etme Sürecinde Arama, Geliştirme Ve Terk Etme Faaliyetlerinin Türkiye Muhasebe ve Finansal Raporlama Standartları Kapsamında Muhasebeleştirilmesi”, Mali Çözüm, Ocak-Şubat, ss. 55-76. 
Kara, Suat ve Topçu, Dilek (2015), “TMS-20 Devlet Teşviklerinin Muhasebeleştirilmesi ve Devlet Yardımlarının Açıklanması Kapsamında Yeni Teşvik Sisteminin Muhasebeleștirilmesi”, World of IFRS Hakemli UFRS Dünyası Dergisi, Ekim-Kasım-Aralık, Sayı:5, ss. $10-29$.

Karapınar, Aydın- Figen Zaif -Torun Salih (2010), "Maden İşletmelerinde Uygulanan Muhasebe Politikaları ve Uluslar arası Finansal Raporlama Standardı-6'nın Getirdiği Düzenlemeler", Gazi Üniversitesi İktisadi ve İdari Bilimler Fakültesi Dergisi, 12(3), ss. 43-68.

Karasioğlu, Fehmi ve Kınalı Fırat (2017), “TMS-20 Devlet Teşviklerinin Muhasebeleştirilmesi ve Finansal Raporlama Süreci”, Selçuk Üniversitesi, Sosyal Bilimler Meslek Yüksekokulu Dergisi, Cilt:20, Say1:2, Kasım, ss. 140-150.

Küçük, Ergün (2018); “Devlet Teşviki Kapsamındaki Düşük Faizli Kredilerin BOBİ FRS Açısından Değerlendirilmesi”, Muhasebe Bilim Dünyası Dergisi, 20(4); Aralık, ss. 761-784.

Madencilik Faaliyetleri Uygulama Yönetmeliği: Resmi Gazete Tarihi: 21.09.2017 ve Resmi Gazete Say1s1: 30187.

Okutmuş, Ercüment-Uyar, Süleyman-Gövce, Muharrem (2015), “Sağlık Turizminde Devlet Teşviklerinin TMS 20 Kapsamında Muhasebeleștirilmesi”, C.Ü. İktisadi ve İdari Bilimler Dergisi, Cilt 16, Say1 2, ss. 63-82.

Onay, Ahmet (2016), "Muhasebe Standartları Kapsamında Devlet Teşviklerinin Muhasebeleştirilmesi”, Aksaray Üniversitesi İktisadi ve İdari Bilimler Fakültesi Dergisi, Cilt:8, Sayı:3,ss. 31-45.

Onocak, Derya ve Çukacı, Yusuf Cahit (2018), "Devlet Teşviklerinin TMS 20, BOBİ FRS ve MSUGT Çerçevesinde Muhasebeleştirilmesi”, Sosyal Bilimler Dergisi, Y11:5, Say1:28, Ekim, ss. 115-130.

Özkan, Azzem ve Aksoylu, Semra. (2012), “Madencilik Endüstrisi: Muhasebe ve Finansal Raporlama", Muhasebe ve Bilim Dünyası Dergisi (MÖDAV), 14(2), ss. 77-97.

Sönmez, Feriştah (2005), "Devlet Teşvik Ve Yardımlarının Muhasebeleştirilmesi", Muhasebe Finansman Dergisi, Sayı:28, ss. 125140. 
M. Kısakürek - S. Elden Ürgüp - M. Tatlı Türkive'de Maden İșletme...

Sönmez, Alper (2016), “Türkiye Maden Sektörü İhracatına Konjonktürel Faktörlerin Etkisi”, Celal Bayar Üniversitesi İ.İ.B.F. Dergisi, Cilt:23, Say1:2, ss. 316-336.

TBMM Maden Araştırması Komisyonu Raporu (2014) “Manisa'nın Soma İlçesinde, Başta 13 Mayıs 2014 Tarihinde Olmak Üzere Meydana Gelen Maden Kazalarının Araştırılarak Bu Sektörde Alınması Gereken İş Sağlığı Ve İş Güvenliği Tedbirlerinin Belirlenmesi Amacıyla Kurulan Meclis Araştırması Komisyonu Raporu”, Sıra Sayıs1: 680, Cilt:1, Aralık.

Tunçez, H. Arif ve Ateş, Alper (2016) "Devlet Teşviklerinin Muhasebeleştirilmesi Ve Devlet Yardımlarının Açıklanması Standardı (TMS 20) Kapsamında Turizm Sektöründe Muhasebe İşlemleri”, Selçuk Üniversitesi Sosyal Bilimler Meslek Yüksekokulu Dergisi, Cilt:19, 41.Y11 Özel Sayıs1, ss. 87-96.

Ulusan, Hikmet (2008), “Türk Muhasebe Hukuku Çerçevesinde Devlet Teşviklerinin Muhasebeleştirilmesi ve Raporlanması”, İktisadi ve İdari Bilimler Dergisi, Cilt:22, Temmuz, Say1:2, ss. 416-433.

Yardımcıŏglu, Mahmut- Çoşkun, Selin-Çoşkun, Sedat-Kocamaz, Hilal (2014), "Maden İşletmelerinde Maden Varlıklarının Edinimi, Hazırlık, Geliştirme ve Arama Giderlerinin TFRS Göre Değerlendirilmesi ve Muhasebeleştirilmesi", Kahramanmaraş Sütçü İmam Üniversitesi İktisadi ve İdari Bilimler Fakültesi Dergisi, Cilt:4, Sayı:2, ss. 71-84.

Yıldız, Feyyaz- Topal, Yusuf- Küçükkahraman, Burak (2012), “Sanayi İşletmelerine Verilen Teşviklerin "TMS 20: Devlet Teşviklerinin Muhasebeleştirilmesi ve Devlet Yardımlarının Açıklanması" Standardı Ișı̆̆ında İncelenmesi ve Muhasebeleştirilmesi”, Afyon Kocatepe Üniversitesi, İ.İB.F. Dergisi, Cilt:XIV, Say1:I, ss. 295-312.

Yolcu, Mehmet ve Sağlam, Necdet (2014), Maden İşletmelerinde TMS/TFRS'ye Uygun Finansal Raporlama ve Kapsamlı Uygulama Örnekleri, Detay Yayınc1lık, Ankara.

https://www.resmigazete.gov.tr/eskiler/2007/11/20071127-2.htm (10.11.2019)

www.ekonomi.gov.tr (Erişim Tarihi: 07.12.2019)

http://www.sbb.gov.tr/temel-ekonomik-gostergeler/\#1539970123300b0aebfc4-3e3b $(21.10 .2019)$ 